\section{BIBLIO COUNS}

Biblio Couns : Jurnal Kajian Konseling dan Pendidikan

Vol. 1, No. 1, 2018, hlm. 1-11

Tersedia Online di jurnal.umsu.ac.id/index.php/biblio

ISSN 2620-3103 (online)

DOI: https://doi.org/10.30596/bibliocouns.v1i1.1941

\title{
Kontribusi Penguatan Guru Mata Pelajaran Dan Kepercayaan Diri Siswa Terhadap Keaktifan Siswa Dalam Belajar
}

\author{
Zamratul Aini ${ }^{1}$, Herman Nirwana ${ }^{2}$, Marjohan $^{3}$ \\ ${ }^{1,2,3}$ Program Studi S2 Bimbingan dan Konseling, Fakultas Ilmu Pendidikan, Universitas Negeri Padang \\ Jalan Prof. Dr. Hamka Air Tawar Padang, Sumatera Barat \\ Korespondensi: zamratulaini@gmail.com
}

\begin{abstract}
The purpose of this reaserch is to describe: (1) reinforcement teacher subjects accepted students, (2) the confidence of students, (3) the activeness of students in learning, , and (4) contribution the reinforcement subjects teachers and confidence individually or together to the activeness of students in learning. This research used quantitative approach and correlation method. The population of this reaserch were 619 students of SMA Pertiwi 1 Padang in the class X and XI. The sampel were 243 students than were chosen by using propotional stratafied random sampling. The instruments used Scale of Activeness Students in Learning with reliability 0,922, the Scale of Reinforcement Teacher with reliability 0,865, and Scale of Self Confidence with reliability 0,915 Likert model. Research data were analyzed using simple regression and regression. The results of this research show that on average: (1) the level of reinforcement teacher subjects were on the category either, (2) the level of the students's confidence are in the category of middle, (3) the level of activeness students are on a high category, (4) reinforcement teacher subjects contribute significantly to the activeness of the students in learning of $15.6 \%$, confidence contributes significantly to the activenes of the students in learning of 17,9\%, and reinforcement teachers subjects and confidence collectively contribute significantly the activiveness student in learning of $25,4 \%$. The implications of the research can be used as input to steer counsellors in providing guidance and counselling services.
\end{abstract}

Keywords: Reinforcement; Self Confidence; Activeness Students Learning.

\begin{abstract}
Abstrak: Tujuan penelitian ini adalah untuk mendeskripsikan: (1) penguatan mata pelajaran guru diterima siswa, (2) kepercayaan diri siswa, (3) keaktifan siswa dalam belajar,, dan (4) kontribusi guru mata pelajaran penguatan dan kepercayaan diri secara individu atau bersama untuk keaktifan siswa dalam belajar. Penelitian ini menggunakan pendekatan kuantitatif dan metode korelasi. Populasi penelitian ini adalah 619 siswa SMA Pertiwi 1 Padang di kelas X dan XI. Sampel adalah 243 siswa dari yang dipilih dengan menggunakan propotional stratafied random sampling. Instrumen yang digunakan Skala Skala Ketrampilan Siswa dalam Pembelajaran dengan reliabilitas 0,922, Skala Penguatan Guru dengan reliabilitas 0,865, dan Skala Percaya Diri dengan reliabilitas 0,915 model Likert. Data penelitian dianalisis menggunakan regresi dan regresi sederhana. Hasil penelitian ini menunjukkan bahwa rata-rata: (1) tingkat penguatan guru mata pelajaran berada pada kategori baik, (2) tingkat kepercayaan siswa berada pada kategori sedang, (3) tingkat keaktifan siswa pada kategori tinggi, (4) subjek guru penguatan berkontribusi signifikan terhadap keaktifan siswa dalam pembelajaran 15,6\%, kepercayaan memberikan kontribusi signifikan terhadap aktivitas siswa dalam pembelajaran 17,9\%, dan memperkuat mata pelajaran dan keyakinan guru secara kolektif berkontribusi secara signifikan siswa yang aktif dalam pembelajaran sebesar 25,4\%. Implikasi dari penelitian ini dapat digunakan sebagai masukan untuk mengarahkan konselor dalam memberikan layanan bimbingan dan konseling.
\end{abstract}

Katakunci: Penguatan, Kepercayaan Diri, Keaktifan belajar siswa. 


\section{PENDAHULUAN}

Keaktifan siswa merupakan aktivitas yang dilakukan siswa berupa keterlibatan dalam proses pembelajaran. Aktivitas tersebut merupakan salah satu faktor penting yang sangat mempengaruhi kelancaran proses pembelajaran. Djamarah (2008) menjelaskan aktivitas artinya kegiatan atau keaktifan. Keaktifan siswa tersebut berbentuk perilaku yang ditunjukkan siswa dalam proses pembelajaran. Menurut Nirwana (2003) perilaku belajar adalah segala aktivitas siswa di dalam kelas yang berkaitan dengan pembelajaran, misalnya memperhatikan (mendengarkan, menyimak) penjelasan guru, membaca materi pelajaran, mencatat penjelasan guru, mengajukan pertanyaan, dan melakukan diskusi kelas.

Menurut Viona \& Suprijono (2014) keaktifan siswa dalam proses pembelajaran sangat penting karena dengan kondisi tersebut dapat mengetahui kemampuan siswa dalam menyerap dan memahami materi. Senada dengan pendapat di atas, Graves (2008:2) menyatakan "When a student is actively involved in his her learning, he or she more likely to truly connect with the material and remember the concept for a long period time”. Dimyati \& Mudjiono (2009) menyatakan bahwa keaktifan siswa dalam peristiwa pembelajaran memiliki bentuk kegiatan fisik yang dapat diamati. Contoh kegiatan fisik adalah aktivitas visual yang meliputi membaca, menulis, dan demonstrasi. Aktivitas lisan meliputi bercerita, tanya jawab, dan diskusi. Aktivitas mendengarkan yang meliputi mendengarkan penjelasan guru, ceramah, dan pengarahan. Aktivitas yang terakhir, yaitu aktivitas menulis seperti mengarang, membuat makalah, dan membuat surat.

Viona \& Suprijono (2014) permasalahan yang terjadi di kelas pada mata pelajaran Sejarah Indonesia saat proses pembelajaran akan dimulai ditemukan banyak siswa yang terlihat malas, mengantuk, dan tidak bersemangat. Pada saat guru menjelaskan materi, hanya dua baris bangku pertama yang memperhatikan sedangkan siswa lainnya tidak fokus dan tidak memperhatikan guru. Selanjutnya, penelitian Afnibar (2011) ditemukan hasil bahwa dalam proses pembelajaran kadangkala guru menemukan beberapa siswa yang tidak memperhatikan, acuh dan bingung, ada yang gelisah, serta berperilaku pasif namun ada juga siswa yang mencatat dengan cepat materi yang diberikan dan ada siswa yang aktif bertanya. Subhan, Fatmaryanti, \& Hidayati (2013), menunjukkan bahwa keaktifan siswa masih kurang terlihat dalam proses pembelajaran, terutama keaktifan siswa untuk bertanya kepada guru tentang materi yang belum dipahami. Hanya sekitar 12 siswa yang berani bertanya tentang materi yang belum dipahami, selebihnya siswa masih pasif bertanya.

Keaktifan siswa dalam proses pembelajaran, tentunya tidak terlepas dari faktor-faktor yang mempengaruhinya. Menurut Ahmadi \& Supriyono (2004) faktor yang mendukung rendahnya keaktifan siswa di dalam kelas, di antaranya berasal dari faktor eksternal (sikap pendidik dan lingkungan) dan internal (dari siswa sendiri). Selanjutnya, Elliot, Kratochwill, Littlefield, \& Travers (1996) menyatakan bahwa faktor yang mempengaruhi perilaku belajar siswa dalam pembelajaran yaitu karakteristik siswa, karakteristik guru, performance guru dalam mengajar, serta kondisi 
lingkungan sekolah. Performance guru dalam mengajar meliputi keterampilan mengajar yang harus dimiliki oleh seorang guru salah satunya keterampilan memberikan penguatan (Usman, 2004). Sedangkan karakteristik siswa meliputi berbagai hal seperti inteligensi, motivasi, kelas sosial, tingkat aspirasi, persepsi, kepercayaan diri, dan sikap (Pohan, 2016). Beberapa variabel yang diduga memberikan kontribusi terhadap keaktifan siswa dalam pembelajaran, yaitu penguatan dan kepercayaan diri.

Pelaksanaan proses pembelajaran yang dilakukan guru, salah satunya kegiatan yang dapat mengaktifkan siswa adalah memberikan penguatan yang merupakan respon terhadap suatu perilaku yang dapat meningkatkan kemungkinan terulang kembali perilaku tersebut (Hannurofik, 2016). Menurut Prayitno (2009:137) "Penguatan merupakan upaya memantapkan tingkah laku yang dapat diterima". Gino (2000:55) menjelaskan bahwa "Penguatan (reinforcement) merupakan respon terhadap tingkah laku yang dapat meningkatnya atau kemungkinan berulang kembali tingkah laku tersebut".

Pemberian penguatan juga bertujuan untuk meningkatkan perhatian siswa terhadap pelajaran, merangsang dan meningkatkan motivasi belajar serta meningkatnya kegiatan belajar. Pemberian penguatan sebaiknya harus bervariasi, agar siswa termotivasi, bergairah, lebih siap menerima materi dan menciptakan suasana yang kondusif dalam belajar. Pemberian penguatan akan mempengaruhi tingkat keaktifan dan partisipasi siswa, bisa dikatakan bahwa memberikan penguatan penting dalam proses pembelajaran. Apabila seorang siswa menerima penguatan berupa pujian dari guru maka dia akan merasa senang karena hasil belajarnya dihargai oleh guru, dari rasa senang itu akan timbul motivasi atau dorongan untuk belajar lebih giat lagi agar mendapat pujian dari gurunya.

Hasil penelitian Abdillah (2009:102) menunjukkan bahwa penerapan kewibawaan pada ketiga sekolah yang paling rendah berada pada penguatan dengan persentase $75,10 \%, 67,69 \%$ dan $65,97 \%$. Hal ini menunjukan bahwa guru belum maksimal menerapkan penguatan dalam proses pembelajaran. Penelitian Prayitno (2005) mengungkapkan bahwa hanya 26,4\% responden menyatakan semua tugasnya betul-betul diperiksa oleh guru, 22,6\% guru mengembalikan tugastugas siswa dengan memberikan catatan perbaikan, 17,9\% guru cenderung tidak memberikan catatan perbaikan atas kesalahan yang dilakukan oleh siswa. Berdasarkan hasil penelitian Misra (2012) secara teori guru telah menerapkan reinforcement skill dalam proses pembelajaran tapi belum sepenuhnya optimal, tepat atau sesuai dengan apa yang diharapkan. Senada dengan hal tersebut, Hannurofik (2016) menyatakan penguatan guru berada pada kategori belum optimal. Hal ini terungkap dalam penelitiannya bahwa pemahaman guru tentang penguatan, kemampuan guru menerapkan penguatan, pengalaman penguatan yang diterima siswa, dan penerimaan siswa terhadap penguatan dari guru masih berada pada kategori cukup. Selain penguatan positif faktor lain yang mempengaruhi keaktifan siswa salah satunya, yaitu kepercayaan diri. 
Al-Hebaish (2012) menjelaskan kepercayaan diri merupakan aspek psikologis yang sangat menentukan keberhasilan siswa dalam pembelajaran. hasil penelitian Wicaksono (2009) menunjukkan bahwa kepercayaan diri berpengaruh positif yang signifikan terhadap hasil belajar siswa di sekolah. Semakin tinggi kepercayaan diri, maka semakin tinggi hasil belajar siswa dan sebaliknya, semakin rendah kepercayaan diri maka semakin rendah pula hasil belajar siswa. Selain itu, Hakim (2002) mengemukakan kesuksesan di dalam bidang apapun akan sulit dicapai oleh seseorang jika tidak memiliki rasa percaya diri yang cukup.

Dengan rasa percaya diri tinggi yang dimilikinya, siswa akan cenderung berani dalam melakukan sesuatu serta dengan mudah berinteraksi di dalam lingkungan belajarnya. Maka keaktifan siswa dalam proses pembelajaran akan terwujud, dengan adanya respon berupa penguatan positif yang diberikan oleh guru dan kepercayaan diri, maka siswa memiliki kemampuan atau keyakinan untuk memahami dirinya ketika melakukan sesuatu. Pemberian penguatan yang diberikan oleh guru kepada siswa serta kepercayaan diri yang dimiliki siswa merupakan bagian yang diduga membuat siswa aktif dalam pembelajaran, keaktifan siswa dianggap sebagai bagian dari perilaku belajar. Untuk itu sikap percaya diri siswa perlu dikembangkan dalam proses pembelajaran. Jika dikaitkan dengan keaktifan dalam belajar, maka siswa memiliki kemampuan dengan penuh keyakinan diri untuk aktif, seperti bertanya, menjawab pertanyaan, maupun mengemukakan pendapat, maka bisa dipastikan bahwa siswa akan menjadi pembelajar yang aktif mengembangkan segala potensinya tanpa melihat dirinya sebagai individu yang tidak berdaya dan tidak mampu melakukan sesuatu.

Berdasarkan uraian di atas, terlihat adanya keterkaitan penguatan dan kepercayaan diri secara bersama-sama berkontribusi terhadap keaktifan siswa dalam belajar. Namun bagaimana besar kecilnya kontribusi antara faktor-faktor tersebut, maka perlu dilakukan penelitian. Hasil dari penelitian inilah yang akan dijadikan acuan dalam penyusunan program BK. Hal inilah yang menjadi dasar penelitian ini dilakukan, karena belum adanya temuan penelitian yang menunjukkan seberapa besar konstribusi penguatan dan kepercayaan diri terhadap keaktifan siswa dalam belajar di SMA Pertiwi 1 Padang. Tujuan penelitian ini untuk mendeskripsikan: (1) Mendeskripsikan gambaran penguatan guru mata pelajaran yang diterima siswa dalam belajar. (2) Mendeskripsikan gambaran kepercayaan diri siswa. (3) Mendeskripsikan gambaran keaktifan siswa dalam belajar. (4) Menguji kontribusi penguatan yang diberikan guru mata pelajaran dan kepercayaan diri secara sendiri-sendiri maupun bersama-sama terhadap keaktifan siswa dalam belajar.

\section{METODOLOGI}

Penelitian ini menggunakan metode kuantitatif dengan teknik korelasional. Populasi penelitian adalah siswa kelas X dan XI SMA Pertiwi 1 Padang berjumlah 619 siswa, dengan sampel 243 dengan teknik propotional stratified random sampling. Instrumen yang digunakan adalah skala keaktifan siswa dengan nilai reliabel sebesar 0,922 , penguatan dengan nilai reliabel 
sebesar 0,865, dan kepercayaan diri dengan nilai reliabel sebesar 0,915 dengan model Likert. Untuk mengetahui kontribusi variabel bebas terhadap variabel terikat, maka data dianalisis dengan regresi sederhana dan regresi ganda. Analisis data dibantu dengan menggunakan program SPSS versi 17.0.

\section{HASIL PENELITIAN}

Data dalam penelitian ini meliputi variabel penguatan guru mata pelajaran $\left(\mathrm{X}_{1}\right)$, kepercayaan diri $\left(\mathrm{X}_{2}\right)$, dan kecanduan keaktifan siswa dalam belajar $(\mathrm{Y})$. Berikut dikemukakan deskripsi data hasil penelitian.

\section{Penguatan Guru Mata Pelajaran}

Secara keseluruhan pendapat siswa tentang penguatan yang diberikan oleh guru, berada pada kategori baik. Dengan rincian yaitu sebanyak 126 dari 243 siswa dengan persentase $51 \%$ berada pada kategori baik. Kemudian, siswa yang berada pada kategori baik sekali, sebanyak 5 siswa dengan persentase $2 \%$, dan kategori cukup sebanyak 101 siswa dengan persentase $41 \%$. Namun, masih ada juga siswa yang berada pada kategori kurang, yaitu sebanyak 11 siswa dengan persentase 4\%. Variasi skor tersebut perlu untuk diperhatikan agar penguatan dapat ditingkatkan.

\section{Kepercayaan Diri}

Secara keseluruhan kepercayaan diri siswa berada pada kategori sedang. Dengan rincian yaitu sebanyak 139 dari 243 siswa dengan persentase 57\% berada pada kategori sedang. Kemudian, siswa yang berada pada kategori sangat tinggi sebanyak 5 siswa dengan persentase $2 \%$, dan kategori tinggi sebanyak 96 siswa dengan persentase $40 \%$. Namun, masih ada juga siswa yang berada pada kategori rendah, yaitu sebanyak 3 siswa dengan persentase $1 \%$. Variasi skor tersebut perlu untuk diperhatikan agar semua siswa dapat meningkatkan kepercayaan diri.

\section{Keaktifan Siswa dalam Belajar}

Secara keseluruhan keaktifan siswa dalam belajar berada pada kategori tinggi. Dengan rincian yaitu sebanyak 155 dari 243 siswa dengan persentase 64\% berada pada kategori tinggi. Kemudian, siswa yang berada pada kategori sangat tinggi, sebanyak 16 siswa dengan persentase 7\%, kategori sedang sebanyak 67 siswa dengan persentase $28 \%$. dan masih ada juga siswa yang berada pada kategori rendah, yaitu sebanyak 3 siswa dengan persentase $1 \%$. Namun,, masih ada siswa yang berada pada kategori sangat rendah yaitu sebesar 2 siswa dengan persentase $1 \%$. Variasi skor tersebut perlu untuk diperhatikan agar semua siswa dapat meningkatkan kepercayaan diri.

\section{PENGUJIAN HIPOTESIS}

Berdasarkan hasil analisis uji hipotesis dengan menggunakan regresi sederhana, maka hipotesis pertama yaitu penguatan guru mata pelajaran berkontribusi secara signifikan terhadap keaktifan siswa dalam belajar sebesar 15,6\%.

Hipotesis kedua, kepercayaan diri berkontribusi secara signifikan terhadap keaktifan siswa dalam belajar sebesar $17,9 \%$. Sedangkan hipotesis ketiga menggunakan regresi ganda yaitu penguatan guru mata pelajaran dan kepercayaan diri secara bersama-sama berkontribusi secara signifikan terhadap keaktifan siswa dalam belajar sebesar $25,4 \%$. 


\section{PEMBAHASAN}

Berikut akan diuraikan pembahasan berdasarkan masing-masing rumusan dan tujuan dalam penelitian ini.

\section{Penguatan Guru Mata Pelajaran}

Hasil analisis deskriptif terhadap skor persentase rata-rata tingkat penguatan yang diberikan guru mata pelajaran kepada siswa berada pada kategori baik yaitu sebesar 68,43\%, dari 243 siswa yang menjadi sampel penelitian. Hasil penelitian di dukung oleh teori, Al Halik (2017) menyatakan bahwa kualitas penguatan guru kepada siswa berada pada kategori baik dengan persentase $81,20 \%$, sedangkan pendapat siswa secara keseluruhan tentang penguatan yang diberikan guru berada pada kategori cukup dengan persentase 76,59\%. Hasil penelitian Wibowo (2013) yang menunjukkan bahwa tingkat pengaplikasian reinforcement guru mata pelajaran berada pada kategori tinggi. Berarti bahwa guru sudah mampu mengaplikasikan penguatan kepada siswa sehingga dengan adanya pemberian penguatan siswa akan menjadi lebih aktif.

Selanjutnya, Prayitno (2009) menjelaskan bahwa kedekatan guru terhadap siswa yang penuh dengan nuansa penerimaan dan menyenangkan akan berdampak pada pendapat dan sikap siswa yang positif terhadap guru. Barnawi \& Arifin (2012) menjelaskan kehangatan akan membuat hubungan baik dan saling mempercayai antara guru dan siswa sehingga penguatan dari guru akan diterima secara positif oleh siswa.

Yusuf (2003) apabila guru hendak memberikan penguatan terhadap siswa atau sekelompok siswa tertentu atas tingkah laku yang ditampilkan, maka penguatan tersebut harus jelas diajukan kepada siswa atau sekelompok siswa yang bersangkutan sehingga nantinya ia dapat merasakan secara langsung bahwa penguatan ditujukan kepadanya. William Lyon Phelp (dalam Ronald, 2012) menjelaskan bahwa siswa tidak akan pernah melupakan kata-kata yang memberikannya semangat, yang diucapkan dengan jujur, penuh rasa hormat, dan penghargaan. Misra (2012) dalam penelitiannya menjelaskan kurang berdampaknya penguatan serta penghambat masih kurangnya penguatan karena penguatan yang digunakan kurang bervariasi, seperti terlalu sering menggunakan penguatan verbal dengan kata-kata bagus dan pujian. Tetapi, apabila bentuk penguatan yang diberikan berupa pujian secara terus menerus juga memberikan kesan yang menjenuhkan bagi siswa.

\section{Kepercayaan Diri}

Hasil analisis data deskriptif terhadap skor rata-rata 67,58\%, yang menunjukkan tingkat kepercayaan diri siswa berada pada kategori sedang. Kepercayaan diri merupakan suatu hal yang kompleks, terkhusus dalam kegiatan keaktifan siswa di kelas. Kepercayaan diri merupakan modal dasar untuk meraih kesuksesan dalam kehidupan.

Goleman (2001:109) menjelaskan bahwa "Siswa yang percaya diri mampu menghadapi tantangan dan mudah menguasai pekerjaan atau keterampilan baru". Hasil penelitian Pohan (2016:73) menunjukkan bahwa "Siswa yang memiliki kepercayaan diri tinggi merupakan proses 
matangnya kepribadian siswa dalam mengatasi perasaan-perasaan negatif yang menghambat rasa percaya diri”. Kepercayaan diri bukanlah suatu hal yang muncul begitu saja dalam diri siswa. Kepercayaan diri tinggi yang telah ada dalam diri siswa memerlukan suatu proses yang cukup panjang untuk mencapainya.

Hasil penelitian Hamdan (2009) menunjukkan bahwa siswa yang mempunyai kepercayaan diri yang tinggi dapat menyadari kemampuan yang dimiliki, optimis dalam menghadapi setiap permasalahan, serta tidak mudah terpengaruh oleh pendapat orang lain, dan tidak ragu-ragu dalam setiap permasalahan yang dihadapi.

Siswa yang mempunyai kepercayaan diri tinggi dapat memahami kelebihan dan kelemahan yang ada pada dirinya. "Kelemahan-kelemahan yang ada pada dirinya dijadikan motivasi untuk mengembangkan kelebihan yang dimilikinya bukan dijadikan penghambat untuk mencapai tujuan yang telah ditetapkan" (Hakim, 2004:6).

\section{Keaktifan Siswa dalam Belajar}

Hasil penelitian menunjukkan bahwa secara rata-rata tingkat keaktifan siswa berada pada kategori tinggi dengan skor rata-rata 115.07, atau dengan persentase sebesar 71.92\%, dari 243 siswa yang menjadi sampel penelitian. Artinya dalam belajar siswa sudah mulai aktif, seperti memperhatikan ke depan saat guru menjelaskan materi pelajaran, menyampaikan pendapat ketika diminta guru, menjawab pertanyaan, mencatat materi pelajaran.

Hasil penelitian Pohan (2016) dapat dipahami bahwa kegiatan merespon benar-benar menjadi indikasi keberhasilan ketiga proses pembelajaran. Pada saat belajar di kelas siswa telah mempersiapkan diri untuk menanyakan, menjawab pertanyaan, dan mengemukakan pendapat terhadap apa yang telah dipelajarinya di rumah.

Sardiman (2008:100) menjelaskan bahwa "Aktivitas belajar adalah suatu kegiatan yang bersifat fisik maupun mental, dalam proses belajar kedua aktivitas harus selalu terikat". Siswa harus terus dibiasakan untuk terus mengulang-ngulang materi pelajaran serta mempersiapkan materi yang akan di bahas, sehingga ketika sampai di sekolah mereka mampu memperhatikan dan mendengarkan materi apa yang di sampaikan guru pada hari itu dalam proses pembelajaran baiknya proses ini maka akan mendorong siswa untuk lebih aktif memberikan respon di kelas.

\section{Kontribusi Penguatan Guru Mata Pelajaran dan Kepercayaan Diri secara Sendiri-sendiri Maupun Bersama-sama terhadap Keaktifan Siswa dalam Belajar}

Berdasarkan hasil temuan penelitian, bahwa penguatan berkontribusi secara signifikan terhadap keaktifan siswa dalam belajar sebesar 15,6\%. Artinya penguatan yang diberikan oleh guru kepada siswa sangat penting, guru harus memahami bahwa pengaplikasian penguatan dalam belajar sangat berpengaruh terhadap keaktifan siswa.

Sedangkan, kepercayaan diri siswa berkontribusi secara signifikan terhadap keaktifan siswa sebesar $17,9 \%$. Artinya, kepercayaan diri merupakan salah satu faktor yang berkontribusi terhadap keaktifan siswa. Hasil penelitian menunjukkan bahwa penguatan guru mata pelajaran dan 
kepercayaan diri secara bersama berkontribusi secara signifikan terhadap keaktifan siswa dalam belajar sebesar $25,4 \%$.

Berdasarkan hasil penelitian yang diperoleh, penguatan guru mata pelajaran dan kepercayaan diri memberikan kontribusi terhadap keaktifan siswa, jika dibandingkan antara keduanya kepercayaan diri sedikit lebih tinggi dari pada penguatan guru mata pelajaran.

Sardiman (2008) menyatakan bahwa penggunaan penguatan yang tepat sasaran dan teknik pelaksanaannya dapat meningkatkan perhatian siswa, membangkitkan dan memelihara perilaku, menumbuhkan rasa percaya diri dan memelihara iklim belajar yang kondusif. Santrock (2010) menjelaskan bahwa tingkah laku yang diberikan penguatan, maka frekuensi respon positif akan meningkat karena diikuti dengan stimulus yang mendukung. Hal ini senada dengan pendapat Mudjiran (2011) yang menyatakan bahwa penguatan terhadap tingkah laku positif sangat efektif untuk merubah tingkah laku seseorang. Dengan demikian, pemberian reinforcement (penguatan) secara tepat dan disegerakan akan mampu mendukung membentuk tingkah laku siswa, sehingga dapat menunjang keberhasilan proses pembelajaranyang dilaksanakan.

Pemberian penguatan oleh guru dalam proses pembelajaran merupakan upaya mengembangkan pribadi siswa dalam mencapai tujuan pendidikan, khususnya berkenaan dengan tingkah laku yang dapat diterima. Pemberian penguatan akan mempengaruhi tingkat keaktifan dan partisipasi siswa, sehingga bisa dikatakan bahwa memberikan penguatan penting dalam proses pembelajaran. Oleh karena itu, kewajaran dalam bentuk pujian dan konsisten dalam memberikan pujian sangat mendukung keberhasilan dari pemberian penguatan kepada siswa.

Kepercayaan diri memiliki peran penting dalam meningkatkan keaktifan siswa dalam belajar. Siswa yang ingin aktif dalam belajar maka mereka harus meningkatkan kepercayaan dirinya. AlHebaish (2012:60) yang menyatakan bahwa kepercayaan diri merupakan faktor yang sangat menentukan partisipasi aktif siswa di kelas. Siswa yang percaya diri yakin bahwa kegiatan yang akan dilakukan dapat berhasil, apabila ternyata gagal maka tidak mudah putus asa tetapi tetap masih mempunyai semangat, tetap bersikap realistis, dan kemudian dengan mantap mencoba lagi (Widarso dalam Rohayati, 2011:370). Hasil penelitian ini relevan dengan hasil penelitian Hamdan (2009) yang menunjukkan bahwa terdapat hubungan positif yang signifikan antara kepercayaan diri dengan motivasi berprestasi siswa. Kepercayaan diri merupakan penentu seseorang untuk berperilaku.

Ketika proses pembelajaran kepercayaan diri siswa sangat dibutuhkan agar keaktifan siswa di kelas akan muncul sehingga suasana kelas akan menjadi kondusif, adanya timbal balik (feedback) antara guru dan siswa, maupun antara siswa dengan siswa itu sendiri. Hasil penelitian Hamdan (2009) menunjukkan bahwa siswa yang mempunyai kepercayaan diri yang tinggi dapat menyadari kemampuan yang dimiliki, optimis dalam menghadapi setiap permasalahan, dan tidak ragu-ragu dalam setiap permasalahan yang dihadapi. Kepercayaan diri dapat dikategorikan sebagai faktor akhir yang paling menentukan aktif atau tidak siswa dalam belajar. 
Kepercayaan diri membentuk siswa yakin dan optimis terhadap dirinya, bahwa merespon adalah solusi untuk ketidaktahuan, maupun memastikan kebenaran yang telah dimiliki (Goel dan Aggarwal, 2012:89). Kepercayaan diri akan menjadi penentu mau atau tidaknya siswa aktif dalam belajar. Al-Hebaish (2012:60) menyatakan bahwa, "No language learning activities will be carried out successfully without self confidence". Keberhasilan pembelajaran bahasa yang melibatkan aktivitas verbal sangat ditentukan oleh kepercayaan diri siswa. Keaktifan merupakan aktivitas siswa yang diwujudkan dalam bentuk verbal.

\section{KESIMPULAN}

Berdasarkan temuan dan pembahasan hasil penelitian, maka dapat dikemukakan kesimpulan sebagai berikut.

1. Pendapat siswa tentang penguatan yang diberikan oleh guru mata pelajaran secara umum berada pada kategori baik.

2. Kepercayaan diri siswa secara umum berada pada kategori sedang.

3. Keaktifan siswa dalam belajar secara umum berada pada kategori tinggi.

4. Penguatan guru mata pelajaran dan kepercayaan diri secara sendiri-sendiri maupun bersama-sama memberikan kontribusi secara signifikan terhadap keaktifan siswa dalam belajar.

\section{SARAN}

Saran yang dapat diberikan kepada beberapa pihak dengan dasar hasil penelitian adalah diharapkan agar siswa dapat aktif dalam belajar, keaktifannya ditingkatkan agar proses belajar menjadi efektif, kemudian disarankan untuk aktif mengikuti pelayanan BK. Kepada Guru BK/Konselor agar dapat membantu siswa untuk meningkatkan keaktifan dalam proses pembelajaran dengan berbagai layanan serta bekerjasama dengan personel sekolah agar mampu meningkatka penguatan dan kepercayaan diri siswa sehingga keaktifan siswa dalam pembelajaran semakin meningkat.

Diharapkan kepada guru mata pelajaran agar mampu memberikan penguatan kepada siswa dalam proses pembelajaran agar keaktifan siswa bisa meningkat. Kepada kepala sekolah disarankan untuk dapat memberikan dukungan penuh kepada guru BK/Konselor, dengan memfasilitasi sebaik mungkin pelaksanaan masuk kelas 2 jam pembelajaran setiap minggu, maupun pelaksanaan layanan BK di luar jam pembelajaran. Serta memotivasi guru agar dapat meningkatkan keterampilannya dalam memberikan penguatan. Kepada peneliti selanjutnya diharapkan melakukan penelitian lanjutan dengan meneliti veriabel lain dan subjek penelitian yang berbeda, yang diperkirakan berkontribusi terhadap keaktifan siswa dalam belajar. 


\section{DAFTAR RUJUKAN}

Abdillah. 2009. "Kondisi Kewibawaan, Kewiyataan dan Mutu Kegiatan Belajar Siswa serta Kaitannya dengan Hasil Belajar Siswa". Disertasi tidak diterbitkan. Padang: Program Pascasarjana UNP.

Afnibar. 2011. "Model Pelayanan Konseling Format Klasikal dalam Kegiatan Belajar Siswa". Disertasi tidak diterbitkan. Padang: UNP.

Ahmadi, A. \& Supriyono, W. 2004. Psikologi Belajar. Jakarta: Rineka Cipta.

Al Halik. 2017. “Aplikasi Penguatan kepada Siswa di Sekolah (Studi Deskriptif pada SMA Negeri Kota Sungai Penuh)". Tesis tidak diterbitkan. Padang: Program Pascasarjana UNP.

Al-Hebaish, S. M. 2012. "The Correlation between General Self-Confidence and Academic Achievement in the Oral Presentation Course". Journal Theory and Practice in Language Studies, 2 (1).

Barnawi \& Arifin, M. 2012. Kinerja Guru Profesional. Yogyakarta: Ar-Ruzz Media.

Dimyati \& Mudjiono. 2009. Belajar dan Pembelajaran. Jakarta: Rineka Cipta.

Djamarah, S. B. 2008. Guru dan Anak Didik dalam Interaksi Edukatif. Jakarta: Rineka Cipta.

Elliot, S. N., Kratochwill, T. R., Littlefield, J., \& Travers, J. F. 1996. Educational Psychology. USA: Brown \& Benchmark.

Gino. 2000. Belajar dan Pembelajaran 1. Surakarta: UNS Press.

Goel, M. \& Aggarwal, P. 2012. "A Comparative Study of Self Confidence of Single Child and Child with Sibling”. International Journal of Research in Social Sciences, 2 (3): 89-98.

Goleman, D. 2001. Kecerdasan Emosi untuk Mencapai Puncak Prestasi. Terjemahan oleh Alex Tri Kantjono Widodo. Jakarta: Gramedia Pustaka Utama.

Hakim, T. 2002. Mengatasi Rasa tidak Percaya Diri. Jakarta: Puspa Swara.

Hamdan. 2009. "Hubungan antara Kepercayaan Diri dengan Motivasi Berprestasi pada Siswa SMUN 1 Setu Bekasi”. Artikel, Bekasi: Fakultas Psikologi Universitas Gunadarma.

Hannurofik. 2016. "Penguatan Guru dalam Pembelajaran. (Studi pada SMA Negeri Kota Jambi)". Disertasi tidak diterbitkan. Padang: UNP.

Misra. 2012. "Reinforcement Skill dalam Pembelajaran PAI”. Jurnal Al-Ta’lim, 1 (1): 38-54.

Mudjiran. 2011. "Pengembangan Model Penugasan Terstruktur Kepada Siswa”. Padang: Sukabina Press.

Nirwana, H. 2003. "Hubungan Tingkat Aspirasi dan Persepsi tentang Belajar dengan Hasil Belajar Matematika Siswa SMU yang Berlatar Belakang Budaya Minangkabau dan Batak". Disertasi tidak diterbitkan. Malang: Universitas Negeri Malang.

Pohan. R. A. 2016. "Kontribusi Kepercayaan Diri dan Persepsi Siswa terhadap Kegiatan Merespon dalam Pembelajaran serta Implikasinya dalam Bimbingan dan Konseling”. Tesis tidak diterbitkan. Padang: UNP. 
Prayitno. 2005. "Studi Pengembangan Aplikasi High Tough dan High Tech dalam Proses Pembelajaran". Penelitian Hibah tidak diterbitkan. Padang: Program Pascasarjana UNP.

Prayitno. 2009. Dasar Teori dan Praksis Pendidikan. Jakarta: Gramedia Widiasarana Indonesia.

Ronald, L.P. 2012. Kiat Nyaman Mengajar di dalam Kelas. Jakarta: Indeks.

Sardiman. 2008. Interaksi dan Motivasi Belajar Mengajar. Jakarta: Raja Grafindo Persada.

Subhan, A., Fatmaryanti, S. D. \& Hidayati, N. (2013). "Keaktifan Bertanya Siswa dengan Menggunakan Model Pembelajaran Aktif Tipe Card Sort pada Kelas X Madrasah Aliyah Wathoniyah Islamiyah Karangduwur”. Jurnal, Purworejo: Universitas Muhammadiyah, 2 (1): 18-20.

Usman, M. U. 2004. Menjadi Guru Profesional. Bandung: Remaja Rosdakarya.

Viona, G. K., \& Suprijono, A. 2014. "Upaya Meningkatkan Keaktifan Belajar Siswa Menggunakan Metode Pembelajaran Aktif Picture and picture pada Mata Pelajaran Sejarah Indonesia Siswa Kelas X Rekayasa Perangkat Lunak 3 di SMK Krian 1 Sidoarjo". Jurnal Pendidikan, 1 (2): 4-12.

Wibowo, A. 2015. "Aplikasi Reinforcement oleh Guru Mata Pelajaran dan Implikasinya terhadap Bimbingan dan Konseling: Studi Deskriptif di SMA Adabiah 2 Padang". Jurnal Ilmu Pendidikan. Padang, 5 (2).

Wicaksono, D. 2009. "Pengaruh Kepercayaan Diri, Motivasi Belajar sebagai Akibat dari Latihan Bolavoli terhadap Prestasi Belajar Atlet di Sekolah". Tesis tidak diterbitkan. Program Pascasarjana Universitas Negeri Jogjakarta: Jogjakarta.

Yusuf, S. 2003. Psikologi Perkembangan Anak dan Remaja. Bandung: Remaja Rosdakarya. 